\title{
The Correlation of Femur Length with The Body Length of Proboscis Monkey
}

\author{
Ariana ${ }^{1}$, Irma Padeta $^{1}$, Arvendi Rachma Jadi ${ }^{1}$, Hery Wijayanto ${ }^{1,}{ }^{*}$, Teguh Budipitojo, Slamet Raharjo ${ }^{2}$, Amalia Rezeki $^{3}$, \\ and Heri Budi Santoso ${ }^{4}$ \\ ${ }^{1}$ Department of Anatomy, Faculty of Veterinary Medicine, Universitas Gadjah Mada, Yogyakarta, Indonesia, 55281 \\ ${ }^{2}$ Department of Internal Medicine, Faculty of Veterinary Medicine, Universitas Gadjah Mada, Yogyakarta, Indonesia, 55281 \\ ${ }^{3}$ Sahabat Bekantan Indonesia Foundation, Banjarmasin, South Kalimantan, 70122 \\ ${ }^{4}$ Department of Biology, Faculty of Mathematic and Natural Science, Lambung Mangkurat University, South Kalimantan, 70123
}

\begin{abstract}
The proboscis monkey is an endemic primate of Kalimantan Island, Indonesia. According to the International Union for Conservation of Nature (IUCN), proboscis monkey was classified as endangered species. Anatomical data of proboscis monkey has not been available yet. As endemic and endangered primate, morphology and morphometric data of proboscis monkey are important for forensic reference. The purpose of this study was to investigate the correlation between femur and body length of the proboscis monkey. The anatomical analysis used three proboscis monkey from the rehabilitation center, Sahabat Bekantan Indonesia (SBI), Banjarmasin, South Kalimantan. The femur and body length were measured by digital caliper in millimeter $(\mathrm{mm})$. The result showed that there was a strong correlation between femur and body length of the proboscis monkey. The body length of proboscis monkey might be determined by femur length with linear regression $y=0.2682 \mathrm{x}$ +347.85 . In conclusion, there was a positive correlation between femur and body length of proboscis monkey in South Kalimantan.
\end{abstract}

\section{Introduction}

The Proboscis monkey is one of the endemic primates in Indonesia, which is belonging to the Colobinae subfamily $[1,2]$. The habitat is limited to the mangrove forest and peat swamp, which have been interfered with human activity [2] with the result that $20-80 \%$ of proboscis monkey's habitat decreased [3]. The decrease of habitat is associated with the extinction rate of proboscis monkey because this primate is intolerant to habitat destruction $[4,5]$.

According to the IUCN assessment, proboscis monkey classified as an endangered species [3]. Indonesian ministry of environment and forestry has declared that this species is protected and must be increased in population. Previous studies about proboscis monkey are still limited to the distribution of population, ecology, and behavior, as well as the external morphological characteristics. Anatomical data is an important parameter for forensic reference to determine body weight and body length estimation in various age and sex. The femur is one of the large and strong bones. This bone is most often found and used for forensic purposes. The purpose of this study was to investigate the correlation of femur length with a body length of the proboscis monkey. The outcome of this study will provide a scientific base for forensic study. Besides, the result can be also used for supporting other morphology, behavior, ecology, and territory distribution study of proboscis monkey to promote conservation implementation in Kalimantan.

\section{Materials and Methods}

This study used three proboscis monkey from Sahabat Bekantan Indonesia (SBI) foundation, Banjarmasin, South Kalimantan. The study was approved by the ethical committee of Faculty of Veterinary Medicine, Universitas Gadjah Mada, Yogyakarta.

The femur and body length was measured by a digital caliper (Krisbow KW06-423) and tape meter in millimeter $(\mathrm{mm})$. The femur was palpated and maximum length was measured from head to distal end. Body length was measured from the tip of the nose to the proximal base of the tail. The correlation between the two data was analyzed by Pearson correlation and linear regression analysis method in Microsoft Excel 2016 for Windows 10 [6].

\section{Results and Discussion}

The measurement of femur and body length are presented in Table 1. The mean values were used for the Pearson correlation analysis to determine the correlation between femur and body length. Then, the association between the two variables was examined by linear regression analysis.

The Pearson correlation analysis showed a correlation between femur and body length of proboscis monkey with coefficient value $(r)=0.997$. According to the level of Pearson analysis result interpretation [6], the correlation between the two variables was very strong. The measurement of linear regression was done to find out the association between two variables. The association of femur and body length of proboscis monkey was shown in Figure

*Corresponding author: herykh@ugm.ac.id 
1.

Table 1. The mean values of femur and body length measurement of the proboscis monkey.

\begin{tabular}{ccc}
\hline Sample & $\begin{array}{c}\text { Femur length } \\
(\mathrm{mm})\end{array}$ & $\begin{array}{c}\text { Body length } \\
(\mathrm{mm})\end{array}$ \\
\hline 1 & 170.71 & 397.50 \\
2 & 239.29 & 414.67 \\
3 & 303.92 & 435.67 \\
\hline
\end{tabular}

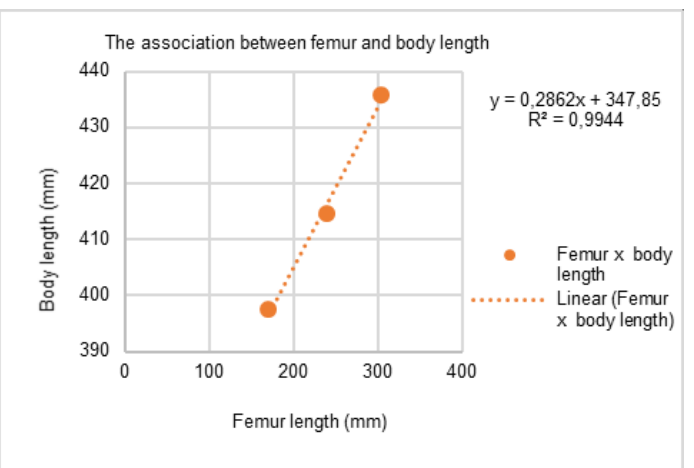

Figure 1. The linear graph between femur and body length. The very strong positive correlation was shown by the upward-sloping line.

Table 2. The differences between measurement and calculation of body length of proboscis monkey

\begin{tabular}{cccc}
\hline Sample & $\begin{array}{c}\text { Body length } \\
\text { measurement } \\
(\mathrm{mm})\end{array}$ & $\begin{array}{c}\text { Body length } \\
\text { calculation by } \\
\text { equation } \\
(\mathrm{mm})\end{array}$ & $\begin{array}{c}\text { The } \\
\text { difference in } \\
\text { body length } \\
(\%)\end{array}$ \\
\hline 1 & 397.50 & 396.71 & 0.20 \\
2 & 414.67 & 416.33 & 0.40 \\
3 & 435.67 & 434.83 & 0.19 \\
\hline
\end{tabular}

The upward-sloping line indicated that the correlation coefficient between femur and body length was positive. The positive correlation between the two variables showed that when the femur length increased, the body length increased as well [7]. Linear regression was applied to examining how the body length is affected by femur length. According to the linear graph, the R-square value of the correlation between femur and body length of the proboscis monkey is 0.9944 . The value indicated that a body length of $99.44 \%$ is affected by femur length. The body length measurement could be obtained by the regression equation:

$$
\begin{gathered}
y=0.2862 x+347.85 \\
y=\begin{array}{c}
\text { body length; } x=\text { femur } \\
\text { length }
\end{array}
\end{gathered}
$$

According to the equation, the body length could be determined, as shown in Table 2. The differences between measurement and calculation by $\mathrm{the}$ equation of body length were below the standard of tolerance. The standard of tolerance between measured and calculated data is $4-15 \%$ [8]. The difference of data below the standard will be accepted and exceed will be rejected.

All data showed that the percentage of the difference was accepted (below 4\%). Thus, the regression equation could be applied for body length measurement of proboscis monkey on the field if only the femur length which is discovered.

The morphometric study of primates had been often carried out to provide information about behavior and movement $[9,10]$. Besides, morphometric information is important for monitoring body growth and development [11] and bone measurement have a role to provide body size and shape information [12]. Proboscis monkey's femur and body length are measured from the rehabilitation center. Further studies are needed to compare information from the rehabilitation center, captive breeding, and nature. In primates, body growth and development, also body size and shape are affected by dietary, age, sex, and habitat $[13,14,15,16]$.

\section{Conclusion}

A very strong and positive correlation between femur and body length indicated that femur length affected to body length. Besides, body length could be determined by femur length by using the equation.

The author would like to thank the Faculty of Veterinary Medicine for fully funding this study through a competitive research scheme, Sahabat Bekantan Indonesia (SBI) Foundation, Department of Biology, Lambung Mangkurat University and Natural Resources Conservation Centre (BKSDA) Banjarmasin, South Kalimantan for implementation research collaboration.

\section{References}

1. J. Supriatna and E.H Wahyono, Panduan Lapangan Primata Indonesia (Yayasan Obor Indonesia, Jakarta, 2000)

2. M. Bismark, Biologi Konservasi Bekantan (Pusat Pengembangan Hutan dan Konservasi Alam, Bogor, 2009)

3. E. Meijaard, V. Nijman, J. Surpiatna, Nasalis larvatu sso. larvatus, The IUCN Red List of Threatened Species, Version 2019-3 (IUCN, 2008)

4. C.C. Wilson and W.L. Wilson. Folia primatol. 23 (1975)

5. C. P. Yeager, Am. J. of primatology. 26 (1992)

6. Sugiyono, Statistika untuk Penelitian (Alfabeta, Jakata, 2012)

7. A. Petrie and P. Watson, Statistic for Veterinary and Animal Science, Third Edition (John Wile and Sons, Ltd, United Kingdom, 2013)

8. E.M. Hile, H.F. Hintz, N. Hollins, J. zoo wildlife med. 28, 4 (1997)

9. K.D. Hunt, Am. J. phys. anthropol. 86 (1991)

10. D.M. Doran, Am. J. phys. anthropol. 91 (1993)

11. S.R. Leigh, Evol. anthropol issues news rev. 3 
(2005)

12. N. Morimoto, M.S Ponce de Leon, T. Nishimura, C.P.E. Zollikofer, Anat. rec. 294 (2011)

13. M.T. O'mara, A.D. Gordon, K.K Catlett, C.J. Terranova, G.T. Schwatz, Am. J. of phys anthropol. (2012)

14. A. Bosket and R. Coleman, J. den. Res. (2010)

15. R. Nap and H. Hazewinkel, Vet quart. (1994)

16. I. Gkiatas, M. Lykissas, I. Kostas-Agnantis, A. Korompilias, A. Batistatou, A. Beris. Am. J. Orthop. (2015) 